\title{
PEMBANGUNAN: PASAR VS KOMUNITAS
}

\author{
Ristya Arinta Safitri \\ Praktisi Arsitektur \\ Email: ristyaarintasafitri@gmail.com
}

\begin{abstract}
ABSTRAK
Pembangunan sering kali dikaitkan dengan hal yang bersifat fisik maupun material. Sedangkan pada hakikatnya, pembangunan meliputi dua unsur, yaitu materi yang dihasilkan dan manusia yang menggerakan pembangunan. Pembangunan di Indonesia pada umumnya menitik beratkan pada materi, terutama ekonomi dan infrastruktur yang ingin dicapai dan mengesampingkan pembangunan masyarakat di dalamnya. Pembangunan ekonomi dilakukan untuk merespon datangnya pasar bebas, sehingga pembangunan ekonomi yang ada berbasis pasar. Hal ini kurang sesuai dengan sifat dasar masyarakat Indonesia yang bersifat komunal, berbasis komunitas. Dalam pasar, modal dan keuntungan adalah hal yang utama, sedangkan dalam komunitas kesejahteraan masyarakat, kebersamaan merupakan hal yang utama. Di Indonesia, komunitas atau Usaha Kecil Menengah dengan komoditas belum dapat berkembang dengan baik karena keterbatasan modal dan kurangnya pemasaran. Sebagai contoh, UKM penghasil gula semut di Kabupaten Kulonprogo. UKM berhasil memproduksi gula semut yang memenuhi kualitas standar internasional. Akan tetapi, karena keterbatasan modal dan kurangnya pemasaran pengeksporan gula semut belum dapat dilakukan secara maksimal. Pemerintah Kabupaten Kulonprogo kemudian mulai aktif mengembangkan komoditas ini dengan mendatangkan investor dan memberikan bantuan alat modern untuk meningkatkan produktivitas UKM. Hal ini perlu diperhatikan lebih lanjut, karena bisa saja dengan investor dan alat modern, pengrajin justru kehilangan pekerjaan dan hanya mengejar keuntungan. Komunitas dalam UKM harus terus melakukan inovasi agar mampu bersaing dalam pasar. UKM yang mampu masuk dalam pasar akan mendatangkan investor untuk membantu pengembangan komoditas sehingga masyarakat dan investor akan mendapatkan keuntungan seperti yang diharapkan.
\end{abstract}

\section{Kata Kunci: Pembangunan, Dualisme, Pasar, Komunitas, UKM}

\section{PENDAHULUAN \\ Latar Belakang}

Pembangunan sering diartikan sebagai usaha memajukan kehidupan masyarakat dan warganya, dalam sifatnya material (Tjokrowinoto, 1989, cit. Budiman, 1995). Bersifat material maksudnya adalah lebih menitikberatkan pada bidang ekonomi. Hal ini tidak sepenuhnya benar, karena dalam berbagai aspek kehidupan masyarakat selalu ada usaha untuk maju, tidak hanya dalam bidang ekonomi akan tetapi infrastruktur, kreatifitas, mental, kesehatan, dan sebagainya. Sedangkan Soekanto (1982) menyatakan, pembangunan sebagai suatu proses perubahan disegala bidang kehidupan yang dilakukan secara sengaja berdasarkan suatu rencana tertentu, dimana proses pembangun- an itu sendiri harus bertujuan untuk meningkatkan taraf hidup masyarakat, baik secara spritual maupun material.

Sedang secara terminologi, pembangunan ialah perubahan yang direncanakan dan dilaksanakan oleh sebuah negara untuk mencapai masyarakat yang adil dan sejahtera (Saptari, 1997). Di Indonesia pembangunan identik dengan istilah development, modernization, westernization, empowering, industrialization, economic growth, europanization, bahkan istilah tersebut juga sering disamakan dengan term political change. Banyaknya terminologi pembangunan menunjukan bahwa pembangunan tidak selalu berkaitan dengan ekonomi maupun fisik bangunan. Meskipun pembangunan secara arti kata maupun terminology memiliki arti 
yang luas, pada dasarnya berkaitan dengan usaha dan proses menuju sesuatu yang lebih baik melalui sebuah rencana.

Pembangunan sebenarnya meliputi dua unsur pokok; pertama, masalah materi yang mau dihasilkan dan dibagi, dan kedua, masalah manusia yang menjadi pengambil inisiatif, yang menjadi manusia pembangun. Pembangunan tidak hanya berurusan dengan produksi dan distribusi barang-barang material; pembangunan harus menciptakan kondisi - kondisi manusia bisa mengembangkan kreatifitasnya (Budiman, 1995: 13-14). Materi yang akan dihasilkan dan dibagi dalam pembangunan mempengaruhi rencana yang disusun untuk mencapai kemajuan atau kondisi yang diinginkan sebagai hasil dari pembangunan. Sedangkan manusia sebagai pengambil inisiatif berperan sebagai pelaksana dari rencana yang telah disusun. Tanpa materi dan manusia, pembangunan tidak akan berjalan.

Indonesia sebagai sebuah negara yang sedang berkembang, pembangunan merupakan tolak ukur kemajuan bangsa dan negara. Semakin banyak pembangunan di daerah semakin baik atau semakin maju negara. Sehingga daerah-daerah di Indonesia berlomba - lomba untuk melakukan pembangunan. Pembangunan yang berlangsung seringkali hanya berbasis pada materi atau tujuan yang ingin dicapai dan melupakan bahkan meninggalkan unsur manusianya, dalam hal ini masyarakat.

Pembangunan pada daerah-daerah di Indonesia seringnya lebih fokus dalam pembangunan ekonomi dan infrastruktur. Pembangunan ekonomi memegang peranan yang sangat penting dalam kemajuan daerah terutama merespon tantangan persaingan bebas yang semakin nyata. Diharapkan dengan pembangunan di bidang ekonomi, daerah akan bertahan dan tidak tersingkir menghadapi persaingan bebas. Pembangunan di bidang ekonomi sering 'diwakili' oleh pusat perbelanjaan atau secara luas disebut sebagai pasar yang tinggi nilai jualnya dan dikuasai oleh pihak-pihak yang memiliki modal tinggi. Dalam pasar kegiatan yang terjadi sangat berdasar pada prinsip supply dan demand.

Pada pasar, keuntungan adalah hal utama, dan hal lain diabaikan termasuk masyarakat sekitarnya. Sehingga seringkali pembangunan bernilai ekonomi tinggi seperti pasar mengabaikan pembangunan manusia dalam hal ini masyarakat di sekitarnya. Pembangunan ekonomi yang tidak sejalan dengan kepentingan masyarakat akan menyebabkan adanya jurang sehingga pembangunan tidak mencapai hasil maksimal. Sedangkan pembangunan ekonomi berbasis masyarakat dinilai tidak mampu menjawab tantangan persaingan bebas. Pembangunan ekonomi berbasis masyarakat dianggap sudah tidak tepat diterapkan terutama pada negara berkembang yang sedang mengejar ketertinggalan dari negara maju. Akan tetapi, pembangunan ekonomi berbasis pasar belum tentu mampu menjawab kebutuhan masyarakat Indonesia yang masih menjunjung tinggi budaya dan bersifat komunal.

Dari beberapa pandangan tersebut, kemudian muncul pertanyaan, pembangunan ekonomi berbasis apakah yang mampu menjawab tantangan persaingan bebas akan tetapi juga memperhatikan kemajuan masyarakat, apakah permbangunan ekonomi berbasis pasar ataukah berbasis komunitas yang tepat untuk Indonesia.

\section{Pengertian Pasar dan Komunitas}

Pasar menurut Kamus Besar Bahasa Indonesia berarti tempat orang berjual beli. Secara umum, pasar berarti tempat terjadinya transaksi jual beli (penjualan dan pembelian) yang dilakukan oleh penjual dan pembeli yang terjadi pada waktu tertentu.

Menurut William J. Stanton (1993) pasar dapat didefinisikan sebagai berikut: Pasar adalah orang-orang yang mempunyai keinginan untuk puas, uang untuk berbelanja dan kemauan untuk membelanjakannya. Stanton mengemukakan bahwa pasar bukan lagi merujuk hanya pada suatu tempat, akan tetapi lebih kepada pelaku yang terlibat dalam kegiatan jual beli.

Pasar dimaksudkan untuk mengatur pengalokasian sumberdaya yang optimum untuk mencapai tingkat pertumbuhan ekonomi yang tinggi melalui kebebasan individu dan kapital yang dimiliki oleh swasta. Pasar tidak membutuhkan perencanaan dan pengawasan dari pihak manapun, baik pemerintah atau institusi lainnya, biarkan saja apa adanya dan suatu invisible hand akan mengatur kembali kearah keseimbangan (Smith, 1776). Dalam pendapatnya tersebut Smith menyebutkan 
bahwa pasar sangat dikuasai oleh individu dan kapital atau modal yang dimiliki swasta. Pendapat Smith ini kemudian merujuk pada pasar sebagai ekonomi kapitalis.

Secara tekstual dalam teori ekonomi, pasar mengandung unsur permintaan, penawaran, dan harga. Tiga hal ini merupakan hal yang mendasari terjadinya mekanisme pasar. Tanpa tiga hal tersebut mekanisme pasar tidak akan terjadi. Peranan manusia dalam mekanisme pasar tidaklah besar, yang lebih berperan adalah modal.

Stanton menyebutkan ada 3 unsur penting di dalam pasar yaitu; Orang dengan segala keinginannya, daya beli mereka, kemauan untuk membelanjakannya. Individu dengan modal memegang peranan penting dalam pasar. Sedangkan komunitas peranya tidak disebutkan dalam pasar.

Dalam pasar, masyarakat akan terbagi dua golongan yaitu pemilik sumber daya produksi dan masyarakat pekerja. Secara pasti akan menimbulkan kesenjangan dan memunculkan konflik sosial. Hal tersebut muncul karena pada dasarnya semua individu dalam sistem pasar mengejar keuntungan pribadi sebanyak-banyaknya berdasar modal dan kekuatan yang dimiliki tanpa memperhatikan akibat pada lingkungan sosialnya atau komunitasnya.

Komunitas berasal dari bahasa Latin communitas yang berarti "kesamaan", kemudian dapat diturunkan dari communis yang berarti "sama, publik, dibagi oleh semua atau banyak". Secara bahasa, komunitas merujuk pada publik atau orang banyak dengan kesamaan. Menurut Soenarno (2002), komunitas adalah sebuah identifikasi dan interaksi sosial yang dibangun dengan berbagai dimensi kebutuhan fungsional. Dalam pendapatnya Soenarno mengungkapkan bahwa kesamaan yang mengikat suatu komunitas adalah kebutuhan fungsional.

Menurut Kertajaya Hermawan (2008), komunitas adalah sekelompok orang yang saling peduli satu sama lain lebih dari yang seharusnya, dimana dalam sebuah komunitas terjadi relasi pribadi yang erat antar para anggota komunitas tersebut karena adanya kesamaan interest atau values. Kertajaya mengungkapkan bahwa dalam komunitas ada ikatan emosi yang terjadi didalamnya. Satu sama lain anggota saling peduli dengan dasar hubungan yang terjadi adalah kesamaan interest.

Dari beberapa pengertian diatas, dapat dimengerti bahwa yang menjadi poin penting dalam komunitas adalah adanya kesamaan yang membentuk ikatan dalam kelompok. Kesamaan ini dapat berupa kebutuhan fungsional, kesamaan nilai, kesamaan ketertarikan, hingga kesamaan tujuan.

Dalam pembangunan, komunitas dapat menjadi aset dalam proses pembangunan, terlebih perannya sebagai masyarakat yang telah solid dengan satu tujuan. Menurut Somodiningrat (1996), pembangunan yang berorientasi pada masyarakat memberi kesempatan pada setiap anggota masyarakat untuk ikut serta dalam proses pembangunan dan menikmati hasil pembangunan sesuai tingkat kemampuannya. Sedangkan menurut Hasan Purbo, Commnunity Based Development adalah salah satu proses pembangunan melalui kesepakatan komunitas yang disusun dalam proses interaktif dan melibatkan berbagai aktor terkait, membentuk jejaring komunitas (sumberdaya) untuk mendukung proses pembangunan dalam rangka menurunkan biaya dan mendapatkan manfaat yang optimal; Sehingga, peran komunitas dalam pembangunan lebih kepada manusia yang menjalankan pembangunan. Selain itu, komunitas juga bisa sebagai komoditas yang dikembangkan dalam pembangunan, khususnya pembangunan di bidang ekonomi.

Pembangunan dengan memanfaatkan komunitas memiliki nilai lebih antara lain; berkembangnya konsep teknologi tepat guna, hak asasi, keadilan, dan kepastian hukum masyarakat terpenuhi, terwujudnya konsep pembangunan berkelanjutan (sustainable development). Semua kelebihan dapat terwujud karena masyarakat berpartisipasi aktif dalam proses pembangunan dan memegang peran penting sesuai dengan kemampuan yang dimiliki. Tidak bergantung modal, kepemilikan bahan mentah, tenaga dan sebagainya. Akan tetapi, dalam pembangunan berbasis komunitas pemerintah (stakeholder) dan masyarakat harus memiliki satu visi dan misi yang sama, sehingga membentuk komunitas besar, sebuah negara. 


\section{PEMBAHASAN}

\section{Fakta Pasar dan Komunitas}

Dalam mensukseskan pembangunan, semua aspek kehidupan harus dipertimbangkan. Pembangunan bidang ekonomi, infrastruktur, sosial kemasyarakatan, hukum, dan sebagainya harus berjalan beriringan agar hasil yang diinginkan tercapai maksimal. Pembangunan bidang ekonomi terutama di negara berkembang mengalami dualisme, antara pembangunan yang berbasis pasar atau pembangunan berbasis komunitas.

Pembangunan berbasis pasar mengedepankan nilai/ value yang akan dicapai. Semua pembangunan didasarkan pada keuntungan/ laba dan kerugian. Pasar akan dikuasai oleh individu dengan sumber daya dan modal, sedangkan yang tidak memiliki modal akan menjadi pekerja (buruh). Kemudian akan timbul konflik sosial, yang kaya akan semakin kaya yang miskin semakin miskin. Sedangkan pembangunan berbasis komunitas, mengedepankan pada ikatan dalam kelompok dan kepentingan bersama. Nilai/ value yang diperoleh dari prosesnya bukan hal yang utama; yang utama adalah kesejahteraan anggota komunitas terpenuhi.

Tidak dapat dipungkuri, pembangunan bidang ekonomi akan lebih cepat berkembang menggunakan sistem pasar. Semua individu yang terlibat dalam sistem pasar bersaing secara baik dan nilai yang dicapai lebih tinggi. Sistem pasar memberikan ruang individu untuk mengembangkan diri untuk mencapai keuntungan pribadi. Perbedaan dan persaingan dalam sistem pasar tidak akan menghambat kemajuan yang bisa dicapai. Selain itu, komoditas yang dikelola pasar akan lebih berkembang dan menghasilkan bagi negara maupun daerah dari segi nilai. Komoditas dalam pasar akan di eksplorasi dan di eksploitasi hingga dapat menghasilkan nilai semaksimal mungkin. Bahkan dalam sistem pasar, komoditas didorong untuk terus berkualitas.

Sistem komunitas lebih menitik beratkan kegiatan pada keuntungan untuk komunitas, bukan pada mengembangkan komoditas yang dimiliki untuk mencapai keuntungan. Komoditas dalam komunitas akan dikelola untuk mencukupi kebutuhan komunitas. Setelah kebutuhan komunitas terpenuhi pengelolaan sisa komoditas menjadi seadanya. Dengan kata lain, komoditas tidak dimanfaatkan secara maksimal.

Di negara berkembang seperti Indonesia, banyak komoditas yang dikembangkan oleh masyarakat maupun komunitas. Sektor industri pertanian, industri kreatif, industri kerajinan, industri makanan adalah beberapa komoditas yang sebagian besar pengelolaanya ada di masyarakat/ komunitas. Dari proses pembuatan hingga pemasaran semuanya dilakukan sendiri oleh komunitas. Komunitas-komunitas ini dalam mengelola komoditi hanya seadanya. Tidak ada visi misi untuk menjadikan komoditas bernilai tinggi secara ekonomi ketika kebutuhan komunitas sudah terpenuhi Akibatnya, industri-industri tersebut justru masuk dalam industri kecil hingga menengah. Industri kecil dan menengah atau UKM adalah kegiatan ekonomi produktif yang berdiri sendiri, yang dilakukan oleh orang perorangan atau badan usaha yang bukan merupakan anak perusahaan atau bukan cabang perusahaan yang dimiliki, dikuasai (UU no 20 Tahun 2008).

Di Indonesia, UKM adalah tulang punggung ekonomi Indonesia. Jumlah UKM hingga 2011 mencapai sekitar 52 juta. UKM di Indonesia sangat penting bagi ekonomi karena menyumbang $60 \%$ dari PDB dan menampung $97 \%$ tenaga kerja. Melihat angka ini, sistem komunitas di Indonesia ternyata mampu berkembang dan menghasilkan, akan tetapi secara nyata komoditas yang dikelola belum maju dan mampu bersaing dalam persaingan bebas.

Komunitas-komunitas dengan sumber daya atau komoditas seharusnya dikelola secara tepat agar bisa berkembang dan tidak jalan ditempat. Pengelolaan oleh komunitas itu sendiri rasanya menghambat komoditas yang ada untuk mencapai maksimal sehingga memberikan value pada komunitas itu sendiri.

Cara mengembangkan komoditas yang paling cepat adalah melalui pasar. Akan tetapi, pasar berorientasi nilai, bukan interest dan kepentingan bersama. Sehingga ketika sebuah komoditas dari komunitas masuk kedalam sistem pasar, akan terjadi konflik. Bisa jadi ketika komoditas yang awalnya dimiliki komunitas dikembangkan oleh pasar, komunitas justru tidak mendapatkan manfaat apa-apa.

Sedangkan apabila komoditas tetap dikelola oleh komunitas dengan modal terbatas, komoditas akan sulit berkembang. 
Akan tetapi, komunitas atau masyarakat akan mendapatkan manfaat dari komoditas tersebut. Disinilah terjadi permasalahan atau konflik antara pasar dan komunitas.

Begitu pula yang terjadi di Indonesia, UKM yang dikelola komunitas memiliki komoditas yang bisa memiliki value tinggi secara ekonomi, akan tetapi komunitas memiliki modal terbatas; sehingga pengembangan UKM menjadi tidak maksimal. Termasuk juga dalam hal pemasaran, komunitas belum mampu melakukan pemasaran seperti yang dilakukan individu dalam sistem pasar.

Apabila komoditas dalam komunitas dikembangkan dengan modal yang besar seperti dalam sistem pasar, komoditas komunitas akan berkembang hingga mampu bersaing di pasar bebas. Dengan masuknya komoditas komunitas (UKM) di dalam pasar, komunitas yang merupakan masyarakat akan ikut berkembang dan maju, serat pasar akan menjadi lebih 'kaya' inovasi dengan beragam jenis komoditi yang di perjualbelikan.

Akan tetapi, komunitas, dalam hal ini UKM, mengalami beberapa kesulitan untuk masuk ke dalam pasar. Kesulitan yang dialami UKM berasal dari faktor internal seperti kurangnya modal, kurangnya pemasaran, rendahnya SDM yang mengerjakan komoditas karena sebagian besar UKM dikerjakan oleh industri rumahan, produktifitas rendah, serta kurangnya jiwa enterprenuer untuk mengembangkan komoditas yang dimiliki. Sedangkan dari faktor eksternal antara lain; kurangnya dukungan pemerintah dalam mengembangkan UKM, masalah perijinan, dan isu peraturan yang mengikat ruang gerak UKM.

Hingga saat ini, hanya sekitar $40 \%$ dari UKM yang ada di Indonesia yang mampu bertahan dan bersaing menghadapi pasar bebas. Dan hanya $10 \%$ dari produk UKM yang masuk kedalam pasar. Produk UKM yang sudah masuk dalam retail sebagian besar karena pemilik atau penggeraknya mampu memasarkan produknya dengan bantuan modal dari investor atau bank. Dengan kata lain, UKM yang telah masuk ke pasar akan mengikuti sistem kerja pasar yaitu dengan modal yang besar, produktifitas yang efektif atau tetap, pemasaran yang baik dan harus mampu bersaing dengan produk lain. Apabila komoditas yang dihasilkan komunitas dikelola dalam sistem pasar, produksi akan dilakukan secara masal sesuai dengan permintaan pasar. Selanjutnya tujuan yang dicapai dari produksi bukan lagi kepentingan bersama tetapi lebih kepada nilai ekonomi. Pada titik ini, komunitas UKM akan kehilangan nilai kepentingan bersama yang menjadi kelebihan komunitas.

Pada sisi yang lain, ketika industri yang dilakukan oleh UKM ternyata berhasil dijual dan menghasilkan keuntungan, seringnya penggagas UKM tidak mampu mengembangkan usahanya. Sehingga UKM hanya bergerak ditempat, hanya mampu melayani dan menghasilkan produk dengan jumlah yang sama. Sedangkan diluar sana, mungkin ada industri modern yang mampu menghasilkan produk yang sama dengan produktifitas tinggi dan strategi pemasaran yang tepat. Lambat laun, UKM akan mati karena tidak mampu bersaing dan memasuki pasar perdagangan yang lebih luas.

\section{Studi Kasus/ Fenomena}

Banyaknya UKM yang digagas oleh komunitas masyarakat di Indonesia menunjukan bahwa sebenarnya tuntutan kesejahteraan masyarakat belum mampu dipenuhi oleh pemerintah, sehingga masyarakat mengusahakan sendiri kesejahteraan diantara mereka dengan membentuk sebuah komunitas yang menghasilkan.

Selain itu, UKM juga merupakan usaha yang menggunakan banyak tenaga kerja, terlebih tenaga kerja yang ada di sekitar pusat UKM tersebut. Industri UKM dapat dikerjakan dirumah tanpa perlu suatu ruang usaha untuk melakukan produksi. Kecilnya modal yang dikeluarkan membuat industri UKM banyak dilakukan oleh masyarakat maupun komunitas. Yang terjadi di Indonesia, satu rumah dalam satu desa menjalankan usaha kecil dengan mengambil tenaga kerja dari tetanggatetangganya, ternyata menghasilkan dan mengambil lebih banyak tenaga sekitar untuk bekerja. Proses pengambilan tenaga kerja sekitar yang terus menerus bisa menjadikan satu desa tersebut sebagai sentra industri kecil.

Sebagai contoh salah satu UKM yang berkembang menjadi industri adalah UKM gula semut di Kabupaten Kulonprogo. Gula semut adalah gula yang dibuat dari bahan baku alami nira aren dan kelapa, yang 
kemudian dikeringkan hingga berbentuk butiran. Industri gula semut awalnya dikerjakan dalam rumah oleh warga dusun yang beralih dari industri gula merah cetak yang mengalami penurunan harga. Harga gula merah semut dianggap lebih tinggi sehingga pengrajin beralih dari gula merah cetak ke gula semut.

Dari satu dusun yang menjadi pengrajin kemudian berkembang menjadi puluhan dusun. Pengrajin-pengrajin ini kemudian ditampung dan membentuk koperasi. UKM gula semut bernaung dibawah Koperasi Jatirogo dan beberapa koperasi lain. Setiap koperasi setidaknya beranggotakan 20-50 pengrajin gula semut.

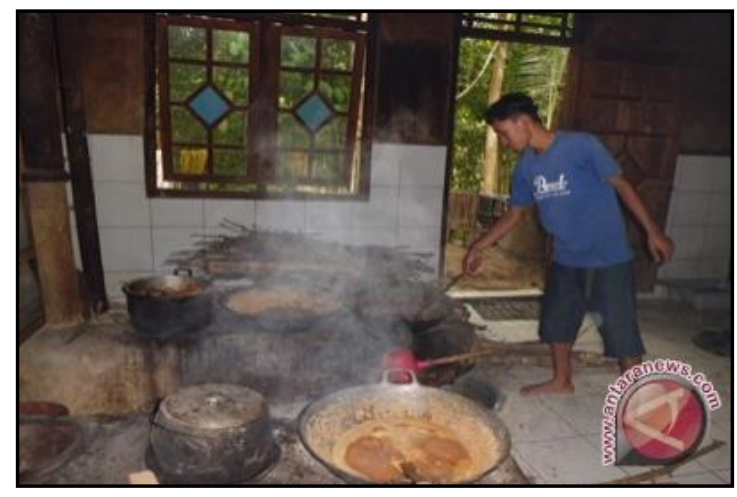

Gambar 1. Produksi Gula Semut Rumahan (Sumber: Antara News, 2012)

Pada tahun 2012, gula semut ditunjuk melalui koperasi dari Kementerian Koperasi dan UKM RI sebagai salah satu rintisan pengembangan produk unggul daerah di Provinsi DIY dan Koperasi Serba Usaha (KSU) Jatirogo ditunjuk sebagai koperasi pelaksana. Hal ini karena gula semut Kulonprogo telah merambah pasar ekspor ke Eropa yang meliputi Belgia, Belanda, Jerman, Inggris, juga ekspor ke Amerika yang meliputi semua bagian Amerika khususnya Amerika Utara serta pasar baru di Australia khususnya kota Melbourne di samping pasar lokal di Jakarta dan Surabaya dengan menggunakan standar produk pangan dan sertifikasi yang telah ditentukan.

UKM gula semut Kulonprogo adalah salah satu UKM yang mampu mengembangkan potensi komoditasnya sehingga mampu menembus pasar internasional. Banyaknya pengrajin gula semut memegang peranan penting dalam menjaga supply gula semut di pasaran. Keberhasilan gula semut menembus pasar internasional terjadi karena adanya bantuan dari pemerintah Kabupaten Kulonprogo serta kerja keras komunitas koperasi setempat.

Dalam sepekan, produksi gula semut di Kuloprogo mencapai 12 ton, dari 12 ton tersebut yang mampu di ekspor baru 9 ton. Sehingga terjadi surplus 3 ton setiap minggunya. Keterbatasan kemampuan ekspor ini karena ekspor gula semut diprakarsai oleh koperasi setempat dan pemerintah kabupaten, sehingga perusahaan pengekspor juga merupakan perusahaan kecil. Seharusnya surplus 3 ton bisa di ekspor atau dipasarkan untuk dalam negeri. Hal ini belum bisa dilakukan karena keterbatasan modal dan jaringan.

Salah satu upaya yang kemudian dilakukan adalah membangun gudang untuk penyimpanan surplus gula semut. Pembangunan gudang gula semut ini mendapat bantuan dari Bank Indonesia sebesar 325 juta rupiah. Upaya ini sebenarnya kurang tepat, karena gula semut yang dikumpulkan dalam bentuk curah belum terkemas, sehingga penyimpanan bisa mengurangi kualitas gula semut yang kemudian tidak sesuai dengan standar produk untuk di ekspor. Gula semut yang tidak bisa di ekspor akan merugikan pengrajin sendiri.

Dalam menangani permasalahan surplus gula semut, perlu melibatkan investor yang mampu mengekspor gula semut ke negaranegara lain. Sehingga gula semut bisa semakin mendunia dengan pangsa pasar yang semakin luas. Akan tetapi, diluar masalah penyaluran hasil gula semut, produksi tetap dalam pengawasan koperasi serba usaha. Sehingga, pengrajin tetap terpenuhi kebutuhannya dan terjamin kesejateraanya.

Pada pertengahan tahun 2012, pemerintah Kabupaten Kulonprogo meresmikan rumah produksi gula semut yang menggunakan mesin dengan harapan meningkatkan produktivitas gula semut. Produktivitas gula semut dinilai rendah karena masih dilakukan secara konvensional oleh industri rumahan. Aplikasi teknologi pengolahan gula semut secara modern dibutuhkan untuk meningkatkan kapasitas, higienitas, dan kontinuitas sehingga dibuat unit pengolahan gula semut dengan proses kontinyu dan peralatan didesain menggunakan bahan stainless steel food 
grade. Hal ini akan sedikit banyak merubah pola produksi gula semut Kulonprogo yang awalnya diproduksi oleh masyrakat desa secara rumahan kemudian di pabrikasi. Tidak menutup kemungkinan pengrajin rumahan gula semut tidak menjadi pengrajin lagi tetapi hanya memasok bahan mentah nira aren saja; Yang artinya pendapatan masyarakat akan berkurang.

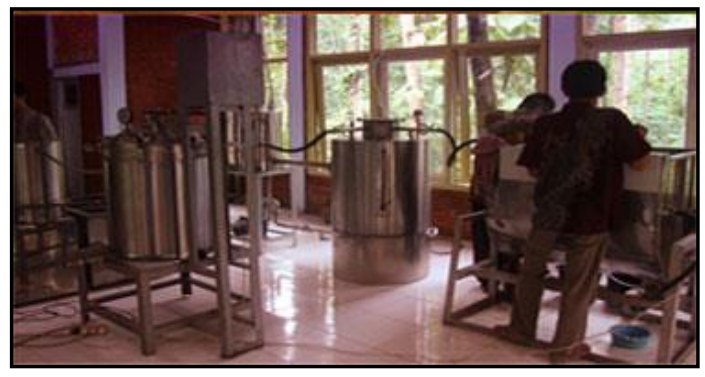

Gambar 2. Produksi Gula Semut dengan mesin (Sumber: Gudegnet, 2012)

Kebijakan pemerintah Kabupaten Kulonprogo untuk menggunakan mesin dalam mengejar kapasitas produksi, menunjukan motif ekonomi yang tinggi. Motif ekonomi tentu tidak dapat dihindari, terlebih ketika komoditas sudah masuk ke pasar internasional dengan tuntutan kualitas komoditas yang tinggi. Produksi gula semut rumahan akan mengakibatkan perbedaan mutu dan kualitas di setiap gula semut yang dihasilkan. Akan tetapi penggunaan mesin sebagai peningkat kapasitas produksi perlu mempertimbangkan hal lain seperti bagaimana efeknya terhadap pengrajin gula semut rumahan.

Gula semut sebagai komoditas ekspor yang dikembangkan dari usaha komunitas harus terus berkembang dan berinovasi agar mampu bertahan dalam persaingan pasar bebas. Salah satunya harus mampu mengemas produksi gula merah secara menarik dan bukan dalam bentuk curah. Kemasan menarik akan meningkatkan daya jual produk. Tahun 2013 ini, Koperasi Jatirogo dan Dinas UMKM mendorong UKM gula semut untuk mengemas produknya dalam sachet sehingga dapat masuk kedalam pasar supermarket atau retail dan perhotelan. Hal ini belum bisa dilakukan oleh pengrajin maupun UKM karena membutuhkan biaya yang tidak sedikit untuk membuat kemasan yang layak jual; Sehingga, pemerintah melibatkan investor untuk membuat pabrik pengemasan gula semut dalam sachet. Ini merupakan tindakan yang harus disambut dengan baik karena dengan adanya investor yang menangani pengemasan dan pemasaran maka produk gula semut dapat mencapai pasar yang lebih luas lagi.

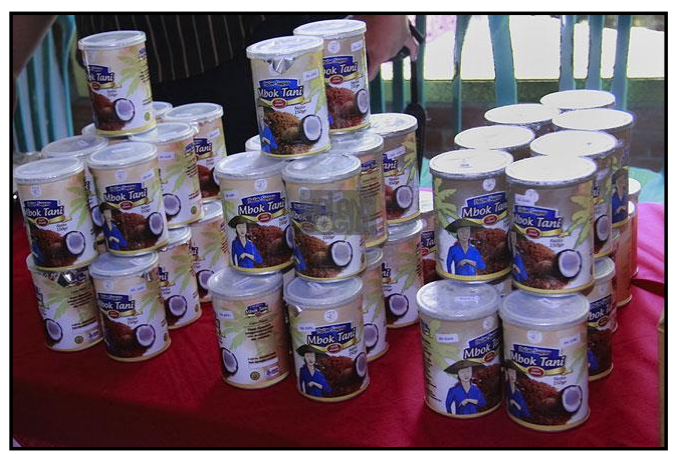

Gambar 3. Kemasan Gula Semut sebagai oleh-oleh (Sumber: Gudegnet, 2013)

\section{PENUTUP}

Pembangunan tidak bisa terlepas dari dua hal yang mendasarinya, yaitu komoditas yang dikembangkan dan manusianya. Pembangunan di bidang ekonomi pada negara berkembang akan selalu mengalami dualisme antara pembangunan yang berbasis pasar yang mengedepankan nilai ekonomis dan modal, dengan pembangunan berbasis komunitas yang mengedepankan kesejahteraan masyarakat dan menuntut peran serta masyarakat dalam pembangunan.

Dalam merespon adanya persaingan bebas, tentu sistem pasar menjadi unggulan, terutama dengan modal dan sumberdaya yang besar. Sedangkan sistem komunitas yang lebih sesuai dengan kondisi masyarakat Indonesia dikhawatirkan tidak bisa bertahan apabila tidak diimbangi juga dengan prinsipprinsip pengembangan sistem pasar. Artinya komunitas-komunitas dengan komoditas harus dirangsang dan dikembangkan hingga mampu masuk ke dalam pasar apabila ingin bertahan menghadapi era persaingan bebas.

Pada studi kasus UKM gula semut Kulonprogo yang telah berhasil masuk ke pasar internasional, keberadaan komunitas masyarakat sebagai pengrajin gula semut dan koperasi sebagai badan usaha pengembang sangatlah penting. Keberhasilan ini perlu ditiru oleh UKM lain. Terutama tentang bagaimana menjaga produktivitas dan kualitas produk, serta bagaimana mengembangkan pangsa pasar. Pemerintah Kabupaten Kulonprogo dan 
DIY yang berperan aktif mendukung UKM gula semut untuk go international juga patut di apresiasi tinggi. Namun ada beberapa hal yang perlu diwaspadai terutama oleh pemerintah sebagai pembuat kebijakan dan oleh komunitas sendiri, antara lain terkait dengan masuknya investor. Investor memang memiliki peranan penting yang dibutuhkan dalam pengembangan produk, akan tetapi produksi sebaiknya tetap dilakukan oleh komunitas dan tidak diambil alih oleh swasta; Sehingga pengrajin gula semut akan tetap mendapat penghasilan dari mengolah bahan mentah menjadi bahan jadi dan koperasi tetap dapat berjalan sebagai pelaksana pengembang produk juga sebagai penjamin kesejahteraan pengrajin anggota koperasi tersebut.

Inovasi-inovasi harus terus dilakukan oleh UKM agar mampu bertahan bersaing di pasar internasional. Apabila UKM dengan komoditas mampu bertahan dalam persaingan pasar internasional, dengan sendirinya akan datang investor yang membantu pengembangan produk.

\section{DAFTAR PUSTAKA}

Irdayanti, Peran Pemerintah dalam Pengembangan UKM Berorientasi Ekspor Studi Kasus: Klaster Kasongan dalam Rantai Nilai Tambah Global dalam Jurnal Transnasional Vol. 3 No. 2 Februari 2012

Kementrian Koordinator Bidang Kesejahteraan Masyarakat, Indonesia, 2013, Jurnal Evaluasi Program Pembangunan Berbasis Masyarakat (CDD) Perkotaan Program Nasional Pemberdayaan Masyarakat Mandiri Perkotaan (PNPM-Urban).

Pasaribu, Rowland: 10 Masalah Dualisme, dalam jurnal JESP Vol.1 No.2 2009

Syahyuti, Pemerintah, Pasar, Dan Komunitas : Faktor Utama Dalam Pengembangan Agribisnis Di Pedesaan, dalam jurnal Pusat Penelitian Dan Pengembangan Sosial Ekonomi Pertanian

Tetiani, Ani. Memudarnya Dualisme Ekonomi: Studi Mobilitas Sosial Komunitas Perkebunan Teh Kertamananh Pengalengan, Jawa Barat, Tesis Sekolah Pascasarjana IPB,2005

http://krisbheda.wordpress.com/2013/03/24/me-rancang-bangun-pembangunan-berbasiskomunitas/

http://www.antaranews.com/print/260984/jangan-serahkan-pembangunan-pada-mekanisme-pasar http://markxpattiasina.blogspot.com/2013/03/definisi-pasar-dalam-pengertian-yang.html

http://dansite.wordpress.com/2009/03/24/definisi-pasar-market/

http://syienaainie.blogspot.com/2010/11/komunitas.html

http://diarru.multiply.com/journal/item/8

http://www.sunspiritforjusticeandpeace.org/2010/11/06/rancang-bangun-pembangunan/

http://comdevmaros.blogspot.com/2013/03/tinjauan-konsep-community-development.html

http://trible-f.blogspot.com/2012/04/pembangunanberbasismasyarakatdalamkonte.html

http://bappeda.kaurkab.go.id/

http://ameliacut.blogspot.com/p/sistem-ekonomi-pasar_01.html 
http://www.kulonprogokab.go.id/v21/Melalui-OVOP-Gula-Semut-Kulon-Progo-Siap-GoInternational_2118

http://www.harianjogja.com/baca/2013/08/04/dikemas-bentuk-sachet-gula-semut-kulonprogomasuk-hotel-434593

http://economy.okezone.com/read/2012/12/27/320/737770/ekspor-gula-semut-kulonprogo-dipatoknaik-40

http://www.seputarukm.com/ukm-dituntut-kreatif-penuhi-keinginan-pasar-global/ 